\title{
EFFECT OF SURGICAL OPERATION FOR BENIGN OVARIAN TUMORS ON ANTI MULLERIAN HORMONE
}

\author{
By \\ Mohammed Aboul-Fotouh Abd El-Mageed, Mahmoud S. Zaki and \\ Ahmed A. El-Tabaakh \\ Obstetrics and Gynecology Dept., Faculty of Medicine, Al-Azhar University, Cairo, Egypt \\ E-mail: moooyadak90@gmail.com
}

\begin{abstract}
Background: Surgical operation for benign ovarian tumors creates a potential risk for the ovarian reserve. Ovarian procedures including excision of cysts (cystectomy) are very commonly performed worldwide for various disorders.

Objective: To study the long term effect of ovarian surgery on blood level of anti mullerian hormone.

Patients and Methods: The present study was a prospective cohort study of patients who have benign ovarian tumor which carried on Patients from December 2019 to October 2020 at Obstetrics and Gynecology Department, Faculty of Medicine, Al-Azhar University.

Results: There was a significant decrease in Anti mullerian hormone ( AMH ) post operatively by $25.79 \%$. There was a significant relation between level of AMH and age of the patients. The old age had a low level of AMH. Also, the bilateral lesion showed a low level of AMH less than the unilateral lesions. The cyst size more than $5 \mathrm{~cm}$ showed a negative relation with level of AMH. The log duration of surgery had a negative effect on the level of AMH. The endometeriotic type showed a significant decrease in AMH level more than the other histopathological findings.
\end{abstract}

Conclusion: Serum AMH levels could be preferred in determining the indication and selection of operative methods for benign gynecologic conditions, especially endometriomas.

Keywords: Surgical Operation for Benign Ovarian tumors, Anti Mullerian Hormone.

\section{INTRODUCTION}

Benign gynecologic diseases are often implicated in fertility problems, and therefore, fertility-preserving interventions are required for such conditions. However, surgical interventions involving the uterus and ovaries have been demonstrated to possibly affect ovarian function, as these interventions might decrease ovarian tissue levels and blood supply to ovaries (Litta et al., 2013).
Among newly developed ovarian reserve tests, the serum level of antiMüllerian hormone (AMH) has been recognized as an improved and informative marker (Iwase et al., 2015).

$\mathrm{AMH}$ is produced by granulosa cells from preantral and small antral follicles, and therefore, AMH levels indirectly represent the total number of follicles, as estimated by the number of earlygrowing-stage follicles. AMH is reported to be a better marker than FSH and inhibin 
$\mathrm{B}$, and it displays similar performance as the antral follicle count in predicting ovarian response (La Marca et al., 2010).

Many researchers have begun using serum AMH levels to evaluate ovarian damage caused by surgical interventions, such as ovarian cystectomy and uterine artery embolization. Moreover, serum AMH levels from conception to menopause in healthy females were analyzed to assess the value of AMH in predicting reproductive lifespan (Kelsey et al., 2011).

Surgical intervention for resection of ovarian cyst may be performed by laparotomy or laparoscopic approach. In cases which oophorectomy is not indicated, ovarian cystectomy is performed. Ovarian cystectomy of endometriosis lesions has been associated with significant decrease in ovarian reserve assessed by measurement of serum AMH level in previous studies; especially when bipolar cauterization has been administered during the procedure. It has been shown that AMH levels recover within 3 months after the surgery but doesn't reach the primary levels (Litta et al., 2013).

The operation of resecting an ovarian cyst (ovarian cystectomy) can be performed either by laparotomy or laparoscopically. Recent studies have reported significant decrease in ovarian reserve, estimated by measurement of serum anti-mullerian hormone (AMH) levels drops significantly after ovarian cystectomy. (Lee et al., 2011) This reduction was partially reversible three months after operation. Some other studies have reported no decrease in the serum level of AMH or damage to ovarian reserve after ovarian cystectomy. In the present study we investigated the effect of laparoscopic ovarian cystectomy on serum AMH in patients with three most common types of ovarian cysts (Dermoid cyst, serous and mucinous cystadenoma) in Shiraz Zeinab Hospital, an affiliated center to Shiraz University of Medical Sciences (Amooee et al., 2015).

The present study aimed to evaluate the surgical effect of benign ovarian tumors on Anti Mulerian Hormone $(\mathrm{AMH})$ in female patient of reproductive age.

\section{PATIENTS AND METHODS}

A prespective study was carried out on 50 patients who have benign ovarian tumors and enrolled to undergo laparoscopic cystectomy at Obstetrics and Gaynecology Department, Faculty of Medicine, Al-Azhar University Hospitals and Kafer Elsheikh General Hospital from December 2019 to October 2020.Before enrollment, they were diagnosed as having uni-/bilateral benign ovarian tumor by ultrasound examination and histologicl confirmed after surgery.

The female patients included in this study gave informed consent.

Inclusion criteria: Age between ( 21-42) years with regular menstrual cycles (21-35 days), have no clinical signs or ultrasound evidence suspicious of ovararian malignancy, have no evidence of any other endocrine disorder such diabetes mellitus, thyroid disorder, hyper prolactinemia, congenital adrenal hyperplasia, Cushing syndrome, or adrenal insufficiency. 
Exclusion criteria: Patients less than (18 years) and more than (45years), malignancy in the ovary, poly cystic ovary, previous adnexal surgery, evidence of pre mature ovarian failure or pre mature menopause, history of infertility or abortion, under any kind of hormonal treatment for at least 6 months.

\section{Patient Evaluation:}

Preoperative Workup, Complete History Taking and Complete Clinical Examination (general and local). All patients underwent to Lab Investigation in the form of measurement of FSH, LH, E2, and $\mathrm{AMH}$ during the early follicular phase (day3) of the month in which surgery was scheduled. Serum AMH was assayed using an enzyme immunoassay (Immunotech SAS, Marseilles, France). And radiological investigations in the form of trasvaginal ultrea sonography, chest X ray, computed tomography (CT), magnetic resonance imaging (MRI), electrocardiography.

Blood sample and trans-vaginal ultrasound examination were then repeated three months after the laparoscopic cystectomy in the same cycle.

\section{Operative techniques:}

All the laparoscopic operations were performed under general anesthesia by the same team of experienced pelvic examination the surgery was done as follows. A three -port laparoscopy technique was used: After an 11- mm trocar was inserted through sub umbilical vertical incision, a10 -mm laparoscope was introduced and the pneumoperitoneum was achieved by inflating with $\begin{array}{lllll}\mathrm{CO}_{2} & (12 \mathrm{mmHg}) ; \text { a lateral } & 10 & -\mathrm{mm}\end{array}$ operating port and a central supra pubic 5-mm operating port were also inserted. After inspection of peritoneal cavity, the cyst was freed and every effort was made to excise the cyst without spilling its contents, especially when the ultrasound diagnosis had revealed a dermoid cyst Removal of the cyst was carried out carefully by identifying the cyst wall and removing it from the ovarian cortex by traction with grasping foreceps. Bipolar electrocoagulation was applied occasionally for hemostasis on the ovarian parenchyma with caution to damage ovarian hillus and vascularity. The sutures were used for ovarian reconstruction. Postoperatively, all patient should be under Close observation for vital signs (ICU admission if indicated), Postoperative increase amount of vaginal bleeding, Laboratory Investigation (AMH, CBC, LFT, S. creatine), Dark or smelly vaginal discharge, Postoperative assessment of any pain or swelling in the abdomen.

\section{Statistical Analysis:}

The Data was collected and entered into the personal computer. Statistical analysis was done using Statistical Package for Social Sciences (SPSS/version 21) software.

Arthematic mean, standard deviation, for categorized parameters, chai square test was used while for numerical data ttest was used to compare two groups while for more than two groups ANOVA test was used. Mann Whitney test was used to compare between the nonparametric data. To find the association between two variables, Spearman correlation coefficient test was used the level of significant was 0.05 . 


\section{RESULTS}

The patients in this study their age ranged from 21-42 yrs. with mean value 32.34-6.69. BMI ranged from 23.3-32.2 with mean value $27.96-2.76$.The parity in our study showed that $26(52 \%)$ with no parity and one or more was 24(48\%). Unilateral laterality was higher with $30(60 \%)$ while bilateral was 20(40\%). Cyst size ranged from 2.90-7.20 with mean value. Operative duration less than $75 \mathrm{~min}$ was $19(38 \%)$ and operative duration more than 75 min was 31(62\%). Operative duration ranged from 65-90 with mean value 77.98-7.53. Amount of blood loss ranged from 26-200 with mean value 121.04-52.53.

Endometriotic type was higher with $21(42 \%)$ followed by dermoid cyst $15(30 \%)$, simple or functional cyst $11(22 \%)$ and cyst adenomas 3(6\%) (Table 1).

Table (1): Distribution of the studied patients group regarding the histopathological findings

\begin{tabular}{|l|c|c|}
\hline Variables & $\begin{array}{c}\text { Number } \\
\text { “n=50” }\end{array}$ & Percent \\
\hline Dermoid cyst & 15 & 30.0 \\
\hline Endometriotic type & 21 & 42.0 \\
\hline simple or functional cyst & 11 & 22.0 \\
\hline cyst adenomas & 3 & 6.0 \\
\hline Total & 50 & 100.0 \\
\hline
\end{tabular}

Pre-operative serum ranged from 2.607.50 with mean value $4.70 \pm 1.53$ and postoperative ranged from 1.61-6.07 with mean value $3.49 \pm 1.19$. Percent of decrease ranged from $38-12$ with mean value $25.79 \pm 4.12$. There was statistical significant relation between pre and postoperative serum AMH and the percent of decreasing (Table 2).

Table (2): Comparison between pre and post-operative serum AMH and the percent of decreasing.

\begin{tabular}{|c|c|c|c|}
\hline Variables & $\begin{array}{c}\text { Pre-operative } \\
(\mathbf{n = 5 0})\end{array}$ & $\begin{array}{c}\text { Post-operative } \\
(\mathbf{n = 5 0})\end{array}$ & Percent of decrease \\
\hline Mean \pm S.D. & $4.70 \pm 1.53$ & $3.49 \pm 1.19$ & $25.79 \pm 4.12$ \\
\hline p value & \multicolumn{2}{|c|}{0.012} \\
\hline
\end{tabular}

There was a statistical significant difference between age, laterality, cyst size and duration of surgery with serum $\mathrm{AMH}$ pre and post-operative $(\mathrm{P}<0.05)$, while there was no statistical significant difference between them and percent of change (Table 3). 
Table (3): Relation between age, laterality, cyst size and duration of surgery in relation to serum AMH pre and post-operative and the percent of change.

\begin{tabular}{|c|c|c|c|}
\hline $\begin{array}{ll} & \text { Parameters } \\
\text { Variables } & \end{array}$ & $\begin{array}{c}\text { Pre-operative } \\
\text { AMH }\end{array}$ & $\begin{array}{c}\text { Post-operative } \\
\text { AMH } \\
\end{array}$ & $\begin{array}{c}\text { Percent of } \\
\text { decrease in AMH }\end{array}$ \\
\hline $\begin{array}{l}\text { Age group } \\
>30 \text { years }(n=50) \\
<30 \text { years }(n=50) \\
P \text { value }\end{array}$ & $\begin{array}{c}3.29 \pm 0.76 \\
5.71 \pm 1.07 \\
0.0126\end{array}$ & $\begin{array}{c}2.46 \pm 0.74 \\
4.24 \pm 0.84 \\
0.0210\end{array}$ & $\begin{array}{c}25.90 \pm 4.83 \\
25.71 \pm 3.60 \\
0.251\end{array}$ \\
\hline $\begin{array}{l}\text { Laterality } \\
\text { Bilateral }(\mathrm{n}=50) \\
\text { Unilateral }(\mathrm{n}=50) \\
\mathrm{P} \text { value }\end{array}$ & $\begin{array}{c}3.66 \pm 0.88 \\
6.25 \pm 0.82 \\
0.001 \\
\end{array}$ & $\begin{array}{c}2.76 \pm 0.79 \\
4.59 \pm 0.77 \\
0.001\end{array}$ & $\begin{array}{c}25.16 \pm 4.37 \\
26.73 \pm 3.61 \\
0.23\end{array}$ \\
\hline $\begin{array}{l}\text { Cyst size } \\
>5 \mathrm{~cm}(\mathrm{n}=50) \\
<5 \mathrm{~cm}(\mathrm{n}=50) \\
\mathrm{P} \text { value }\end{array}$ & $\begin{array}{c}3.26 \pm 0.76 \\
5.65 \pm 1.10 \\
0.001\end{array}$ & $\begin{array}{c}2.44 \pm 0.75 \\
4.20 \pm 0.86 \\
0.002\end{array}$ & $\begin{array}{c}25.94 \pm 4.95 \\
25.69 \pm 3.54 \\
0.271\end{array}$ \\
\hline $\begin{array}{l}\text { Duration of surgery } \\
<75 \text { min. }(n=50) \\
>75 \text { min. }(n=50) \\
P \text { value }\end{array}$ & $\begin{array}{c}3.24 \pm 0.78 \\
5.59 \pm 1.14 \\
0.0025\end{array}$ & $\begin{array}{c}2.41 \pm 0.76 \\
4.16 \pm 0.87 \\
0.0036\end{array}$ & $\begin{array}{c}26.19 \pm 4.96 \\
25.54 \pm 3.58 \\
0.082\end{array}$ \\
\hline
\end{tabular}

$\mathrm{P}$ value was calculated by using Mann-Whitney test.

There was statistical significant relation between histopathological findings and serum $\mathrm{AMH}$ pre and post- operative and the percent of change (Table 4).

Table (4): Relation between histopathological findings and serum AMH pre and post operative and the percentage of change

\begin{tabular}{|c|c|c|c|c|c|}
\hline $\begin{array}{r}\text { Histopathological } \\
\text { findings } \\
(\mathbf{n = 5 0})\end{array}$ & $\begin{array}{c}\text { Dermoid } \\
\text { cyst }\end{array}$ & $\begin{array}{c}\text { Endometriotic } \\
\text { type }\end{array}$ & $\begin{array}{c}\text { Simple or } \\
\text { functional } \\
\text { cyst }\end{array}$ & $\begin{array}{c}\text { Cyst } \\
\text { adenomas }\end{array}$ & $\begin{array}{c}\mathbf{P} \\
\text { value }\end{array}$ \\
\hline $\begin{array}{c}\text { Variables } \\
\text { Pre-operative } \\
\text { AMH }\end{array}$ & $5.49 \pm 1.34$ & $3.56 \pm 1.07$ & $5.53 \pm 1.22$ & $5.60 \pm 1.67$ & 0.013 \\
\hline $\begin{array}{c}\text { Post-operative } \\
\text { AMH }\end{array}$ & $4.16 \pm 1.13$ & $2.60 \pm 0.75$ & $4.07 \pm 0.86$ & $4.29 \pm 1.37$ & 0.002 \\
\hline $\begin{array}{c}\text { Percentage of } \\
\text { decrease in AMH }\end{array}$ & $24.69 \%$ & $26.76 \%$ & $26.05 \%$ & $23.53 \%$ & 0.035 \\
\hline
\end{tabular}

It was found that the age had a positive significant correlation with both serum $\mathrm{AMH}$ at base line and post-operative. Also, cyst size, duration of surgery and amount of blood loss show a positive significant correlation with both serum $\mathrm{AMH}$ at base line and post-operative (Table 5). 
MOHAMMED ABOUL-FOTOUH et al.,

Table (5): Correlation between different studied variables

\begin{tabular}{|c|c|c|c|c|}
\hline \multirow{2}{*}{ Parameters } & AMH & $\begin{array}{c}\text { Serum AMH } \\
\text { base line }\end{array}$ & $\begin{array}{c}\text { AMH at 3 } \\
\text { months post- } \\
\text { operative }\end{array}$ & $\begin{array}{c}\text { Percent of } \\
\text { decrease in } \\
\text { AMH }\end{array}$ \\
\hline \multirow{2}{*}{$\begin{array}{c}\text { AMH at 3 months post- } \\
\text { operative }\end{array}$} & $\mathrm{R}$ & 0.984 & & \\
\cline { 2 - 5 } $\begin{array}{c}\text { Percentage of decrease } \\
\text { in AMH }\end{array}$ & $\mathrm{p}$-value & 0.000 & & \\
\cline { 2 - 5 } & $\mathrm{R}$ & 0.149 & 0.313 & \\
\hline \multirow{2}{*}{ Age } & $\mathrm{p}$-value & 0.302 & 0.027 & \\
\cline { 2 - 5 } & $\mathrm{R}$ & 0.909 & 0.856 & 0.016 \\
\hline \multirow{2}{*}{ BMI } & $\mathrm{p}-$ value & $<0.001$ & $<0.001$ & 0.912 \\
\cline { 2 - 5 } & $\mathrm{p}$-value & 0.014 & 0.001 & 0.113 \\
\hline \multirow{2}{*}{ Cyst size } & $\mathrm{R}$ & 0.923 & 0.994 & 0.434 \\
\cline { 2 - 5 } Duration of surgery & $\mathrm{p}$-value & $<0.001$ & 0.924 & 0.095 \\
\cline { 2 - 5 } & $\mathrm{R}$ & 0.941 & 0.8901 & 0.510 \\
\hline \multirow{2}{*}{ Amount of blood loss } & $\mathrm{p}$-value & $<0.001$ & $<0.001$ & 0.042 \\
\cline { 2 - 5 } & $\mathrm{R}$ & 0.907 & 0.859 & 0.774 \\
\hline
\end{tabular}

\section{DISCUSSION}

The results of our study showed that the age of the patients ranged from (2142) years with a mean value of 32.34 \pm 6.69 . BMI ranged from 23.3-32.2 with a mean value of $27.96 \pm 2.76$.

The distribution of the studied patients group regarding the histopathological findings showed that the endometriotic type was higher with (42\%) followed by dermoid cyst $(30 \%)$, simple or functional cyst $(22 \%)$ and cyst adenomas $(6 \%)$. The majority of the patients were endometriosis in agreement with our study (Jang et al., 2012).

The results of our study showed statistical significant relation between pre and post-operative serum AMH and the percent of decreasing.

In agreement with our study Jeon et al. (2015) showed that preoperative AMH level was significantly lower in endometrioma group than other benign ovarian cyst group in similar sized diameter. Although it is not yet definite whether the ovarian reserve is diminished in patients with endometriosis, several studies demonstrated decreased ovarian reserve in endometriosis patients. Follicular density in cortex from ovaries with endometriomas is lower19 and increased oxidative stress in ovarian cortex around endometriomas might induce follicular depletion.

By space-occupying effects and local reactions, cysts can reduce the amount of functional ovarian tissue available, and endometriosis-related inflammation causes ovulatory dysfunction, disturbed folliculogenesis, decreased oocyte quality, and increased granulosa cell apoptosis (Stilley et al., 2012).

AMH appears in the fetal period and decreases continuously throughout puberty. It becomes undetectable when menopause occurs, identifying it as a typical hormone of reproductive age (Meczekalski et al., 2016).

The levels of AMH reflect the number of preantral follicles; that comprise the 
oocyte pool. Moreover serum levels of AMH are highly correlated with the antral follicle count assessed by ultrasonography and also with AMH concentrations measured in the follicular fluid. 26 Recently, AMH has been used in initial fertility work up and follow up studies on ovarian damage due to chemotherapy, ovarian surgery of diseases like endometriosis (Jeon et al., 2015).

As in endometriosis, majority of studies investigated $\mathrm{AMH}$ as an assessment tool for ovarian reserve depletion after ovarian surgery, predictive responses to assisted reproduction techniques (Streuli et al., 2012).

Endometriosis possibly related to infertility or subfertility. Endometriosis can have direct effect on ovarian reserve and presents with low serum AMH level without previous ovarian surgery or regardless of their fertility state.

Alborzi et al. (2014) emphasized that bilateral presence of endometrioma results in greater decline in serum AMH. They also reported that older groups are susceptible to greater damage to ovarian reserve which is in contrary with our finding. To maintain hemostasis during ovarian cystectomy suturing techniques seem to be associated with less ovarian parenchymal damage than bipolar cauterization; though we suggest further studies to compare the effect of these two procedures on ovarian reserve.

Serum AMH levels appears to correspond well with AFC and ovarian response to hyperstimulation in in vitro fertilization. It was suggested that AMH was a superior marker for predicting ovarian response over either age, $\mathrm{FSH}$, or inhibin B (Ercan et al., 2010).
There are some reports examining the role of AMH for the evaluation of ovarian damage after the ovarian surgery. Most of them were retrospective study or investigated only with endometrioma, or measured the serum AMH only. In this prospective study, we measured the serum $\mathrm{AMH}, \mathrm{FSH}, \mathrm{E} 2, \mathrm{AFC}$, and ovarian volume in women with the endome-trioma and non-endometrioma (Raffi et al., 2012).

Serum AMH levels significantly decreased after laparoscopic cystectomy without the changes of other ovarian reserve markers. Serum AMH could be a delicate marker to provide surgical impact on ovarian reserve. Postoperative serum AMH levels significantly decreased especially in endometrioma group, but not in non-endometrioma group.

In our results, it was found that the level of AMH pre and post-operative was low in patients with age more than 30. In agreement with our study (Elsemary et al., (2018). They found that according to age (>38 years), the baseline serum AMH level was lower in older patients. However, it did not reach a statistically significant level. Three months after surgery, there is a significant reduction in AMH level in both age groups (Kovačević et al., 2018).

On contrast to our results, Hirokawa et al. (2011) demonstrated no significant correlation between the rate of decline in serum AMH level and patients age Celik et al. (2012). Found a weakly negative correlation between age and preoperative AMH level, with no independent age effect on postoperative AMH level.

In this study, it was found that the level of $\mathrm{AMH}$ pre and post-operative was low 
in patients with bilateral findings. This result was agreement with (Elsemary et al., 2018).

There was no consistent report on the effect of bilaterality on the AMH level. In the study by Hirokawa et al. (2011). Bilaterality was the unique factor correlating with the rate of postoperative decline, which was not shown by Celik et al. (2012). Hwu et al. (2011) showed a significantly lower baseline level in bilateral endometriomas and reported a more profound effect of bilaterality on the ovarian reserve, regardless of either conservative or surgical intervention.

In our results, the ovarian cyst size had a significant effect on the level of pre and post-operative AMH. The high size showed a low level of AMH. This result was agreement with (Elsemary et al., 2018) who revealed that there was no significant difference in the baseline AMH level. However, after 3 months of surgery, there was a significant reduction in the levels of AMH. The size of endometrioma did not correlate with baseline and postoperative AMH level. On contrast with our results, they demonstrated that there was an adverse effect of surgery in large and also in small cysts on ultrasonographic results. Ovarian stripping had a significant decrease in residual ovarian volume regardless of the size of the endometrioma, which may result in diminished ovarian reserve and function.

\section{CONCLUSION}

Serum AMH was helpful for counseling patients who desired future fertility, but have benign gynecologic conditions that may require surgical interventions. Serum AMH levels may be preferred in determining the indication and selection of operative methods for benign gynecologic conditions, especially endometriomas.

\section{REFERENCES}

1. Alborzi S, Keramati P, Younesi M, Samsami A and Dadras N. (2014): The im $\neg$ pact of laparoscopic cystectomy on ovarian reserve in patients with unilateral and bilateral endometriomas. Fertil Steril., 101:427-34.

2. Amooee $S$, Gharib $M$ and Ravanfar $P$. (2015): Comparison of anti-mullerian hormone level in non-endometriotic benign ovarian cyst before and after laparoscopic cystectomy. Iranian Journal of Reproductive Medicine., 13(3), 149-154.

3. Celik HG, Dogan E, Okyay E, Ulukus C, Saatli B, Uysal S and Koyuncuoglu $M$. (2012): Effect of laparoscopic excision of endometriomas on ovarian reserve: serial changes in the serum antimullerian hormone levels. Fertil Steril., 97:14721478 .

4. Elsemary YM, Mostafa WFG, El Taher OS, Mahmoud HE and Aly RH. (2018): Serum antimullerian hormone before and after laparoscopic excision of ovarian endometrioma. J Med Sci Res., 1: 30-4.

5. Ercan CM, Sakinci M, Duru NK, Alanbay I, Karasahin KE and Baser I. (2010): AntiMüllerian hormone levels after laparoscopic endometrioma stripping surgery. Gynecol Endocrinol., 26: 468-72.

6. Hirokawa W, Iwase A, Goto $M$, Takikawa S, Nagatomo Y, Nakahara T, Bayasula B., Nakamura T, Manabe $S$ and Kikkawa F. (2011): The post-operative decline in serum antimullerian hormone correlates with the bilaterality and severity of endometriosis. Hum Reprod., 26: 904-910. 
7. Hwu YM, Wu FS, Li SH, Sun FJ, Lin MH and Lee RK. (2011): The impact of endometrioma and laparoscopic cystectomy on serum antimullerian hormone levels. Reprod Biol Endocrinol., 9: $1-8$

8. Iwase A, Nakamura T, Osuka S, Takikawa S, Goto $M$ and Kikkawa $F$. (2015): Anti-Müllerian hormone as a marker of ovarian reserve: What have we learned, and what should we know? Reprod Med Biol., 15(3):127-136.

9. Jang TG, Lee A, Kim YJ, Lee KY, Rhee JH and Park JC. (2012): Age-related normal serum concentrations of antiMüllerian hormone and comparison of ovarian reserve tests in a cohort of healthy Korean women. Fertil Steril., 98: 85-97.

10.Jeon JH, Park SY, Lee SR, Jeong $K$ and Chung HW. (2015): Serum AntiMüllerian Hormone Levels before Surgery in Patients with Ovarian Endometriomas Compared to Other Benign Ovarian Cysts. Journal of menopausal medicine., 21(3): 142-148.

11.Kelsey TW, Wright $P$, Nelson SM, Anderson RA and Wallace WH. (2011): A validated model of serum anti-mullerian hormone from conception to menopause. PLoS One., 6 (7): 1-7.

12.Kovačević VM, Anđelić LM and Jovanović AM. (2018): Changes in serum antimüllerian hormone levels in patients 6 and 12 months after endometrioma stripping surgery. Fertility and Sterility, 110 (6): 1173-1180.

13.La Marca A, Sighinolfi G, Radi D, Argento C, Baraldi E, Artenisio AC, Stabile $G$ and Volpe A. (2010): AntiMullerian hormone (AMH) as a predictive marker in assisted reproductive technology (ART). Hum Reprod Update, 16:113-130.
14.Lee DY, Young Kim N, Jae Kim M, Yoon BK and Chos D. (2011): Effects of laparoscopic surgery on serum antimullerian hormone levels in reproductive-aged women with endometrioma. Gynecol Endocrinol., 27:733-736.

15.Litta P, D'Agostino G, Conte L, Saccardi C, Cela V, Angioni $S$ and Plebani M. (2013): Anti-mullerian hormone trend after laparoscopic surgery in women with ovarian endometrioma. Gynecol Endocrinol., 29: 452-454.

16.Meczekalski B, Czyzyk A, Kunicki M, Podfigurna-Stopa A, Plociennik L, Jakiel G, Maciejewska-Jeske $M$ and Lukaszuk K. (2016): Fertility in women of late reproductive age: the role of serum anti-Müllerian hormone (AMH) levels in its assessment. J Endocrinol Invest., 39: 1259-1265.

17.Raffi F, Metwally $M$ and Amer $S$. (2012): The impact of excision of ovarian endometrioma on ovarian reserve: a system $\neg$ atic review and meta-analysis. J Clin Endocrinol Metab., 97:3146-54.

18.Stilley JA, Birt JA and Sharpe-Timms KL. (2012): Cellular and molecular basis for endometriosis-associated infertility. Cell Tissue Res., 349: 849-62.

19.Streuli I, de Ziegler D, Gayet V, Santulli $P$, Bijaoui G, de Mouzon J and Chapron C. (2012): In women with endometriosis anti-Mullerian hormone levels are decreased only in those with previous endometrioma surgery. Hum Reprod., 27:3294-303. 
تأثثير العمليات الجر احية لأورام المبيض الحميدة على هرمون ضد الموليريان

محمد أبو الفتوح عبد المجيد، محمود سامي ذكي، أحمد عبد القادر الطباخ

قسم النساء والتوليد، كلية الطب، جامعة الأزهر

E-mail: moooyadak90@gmail.com

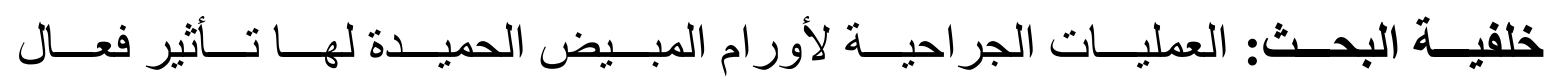
على مخزون البويضات.

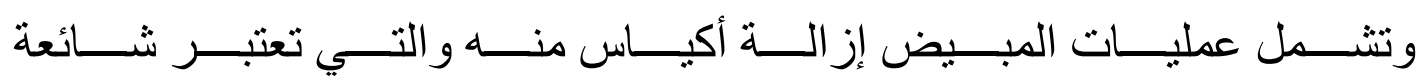
على مستوى العالم لعدة مشاكل متعددة.

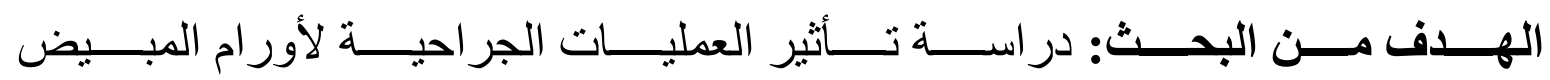
الحميدة على معدلات هرمون ضد الموليريان في الدم.

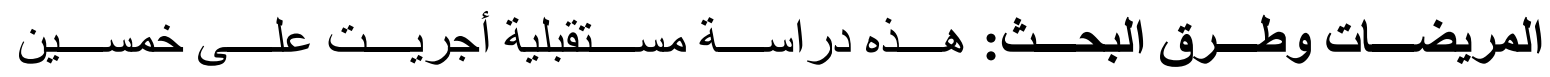

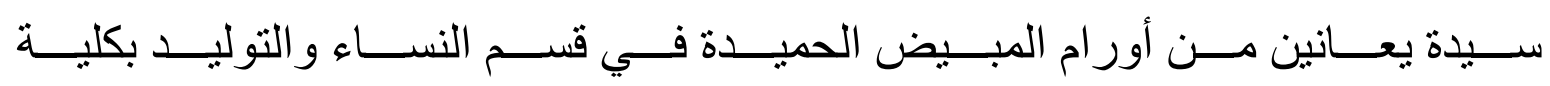
الطب بجامعة الأزهر.

نتــائج البحــث: أظهـرت نتيجــة البحــث أن هنــالك نقصــاً ملحوظــاً فـي هرمــون

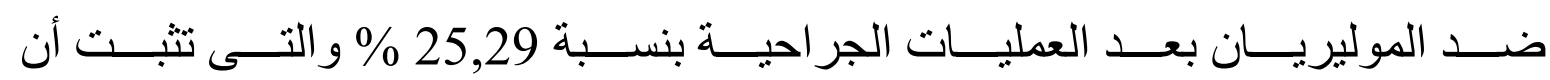
هناك علاقة بين العمليات الجر احيه وهرمون ضد الموليريان.

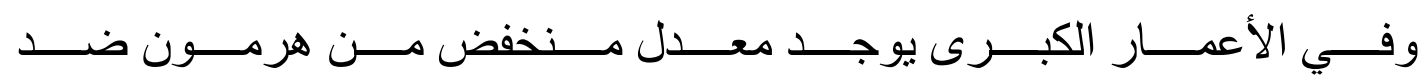

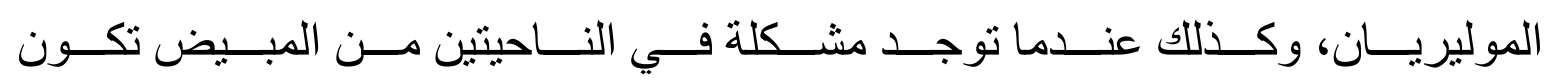

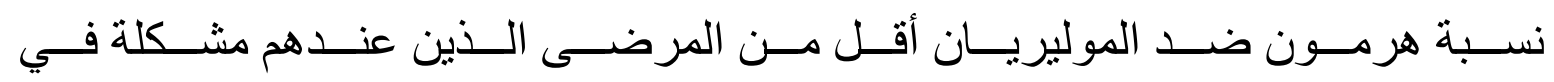

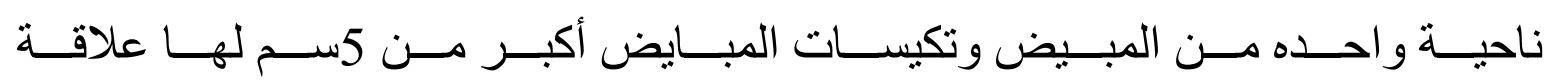




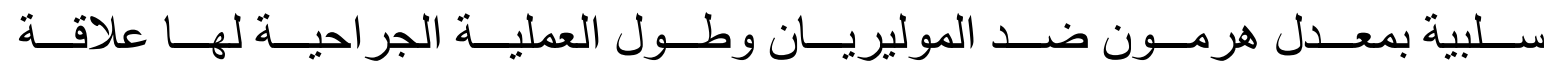
سلبية بمعدل هرمون ضد الموليريان.

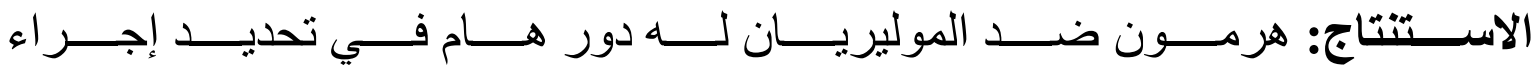
و اختيار العملية لأورام المبيض الحمبدة خاصة البطانة المهاجرة.

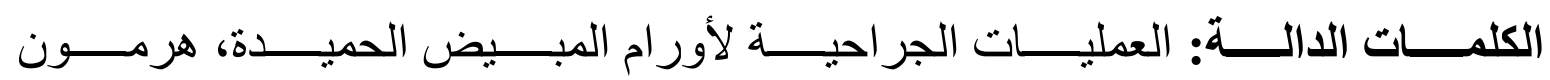
ضد الموليريان، هرمون ضد الموليريان. 